\title{
GEOCHEMICAL INVESTIGATION OF URBANISED TERRITORIES FOR NATURE PROTECTION
}

\author{
VALENTINAS KADŪNAS, ALFREDAS RADZEVIČIUS, \\ VLADAS KATINAS, RIČARDAS BUDAVIČIUS, RIMANTÉ ZINKUTE்
}

\author{
Institute of Geology, T.Ševčenkos 13, 2600, Vilnius, Lithuania \\ T.: 3702235409 , F.: 3702236710
}

\begin{abstract}
Complex geochemical investigations including topsoil, river sediments, water and sediments of dug wells that have been accomplished in Panevežys by Geochemistry department of the Institute of Geology are presented. The methods that were used are described and the main obtained results discussed.
\end{abstract}

\section{Introduction}

Town territories are affected by heavy technogenous contamination. Heavy metals and oil products are one of the most important contaminants characterised by long and diverse toxic impact and very dangerous to biota. The main part of contaminants is deposited and accumulated in topsoil. From there with precipitation they are able to reach groundwater, plants and come back with dust to the atmosphere. The other part of them with runoff and sewage water reaches water reservoirs, mostly rivers and is either removed by river stream or accumulates in bottom sediments forming centres of secondary contamination. Therefore topsoil geochemical investigation is the most important part of complex geochemical investigations and is usually accomplished in all towns. Geochemical research of other sampling media gives additional important information about ecological state of towns. Complex geochemical investigations of Panevėžys in Lithuania accomplished by Geochemistry department of the Institute of Geology are presented. Details can be found in Geochemical atlas of Panevéžys (1997).

\section{Sampling and analytical methods}

Topsoil samples $(\mathrm{N}=2516)$ on the territory of Panevėžys were collected using different sampling density: in central part and industrial zones $-100 * 100 \mathrm{~m}$ regular grid, at greater distance from contamination centres and industrial zones, in housing estates with separate small contamination points $-200 * 200 \mathrm{~m}$ (or even $300 * 300 \mathrm{~m}$ ) regular grid, on the territories of plants and factories $-10 \div 10-50 \div 50 \mathrm{~m}$ most often irregular grid. Samples were taken by the principle of envelope with size $1 * 1 \mathrm{~m}$ from the upper layer of soil (depth $0-10 \mathrm{~cm}$ ), not covered by hard pavement, mainly in green planting or lawn zones with more or less even distribution on the territory.

Sediments of the Nevezis River were sampled by a scoop upstream from the greater sewers. Several samples were also taken from its tributaries Žagienis, Juoda and Aulamas. Their main part, as well as samples from Nevezzis upstream the town was used for background estimation. For geochemical mapping there have been used 40 river sediment samples.

Well sediment samples were taken twice per year at 29 points situated in different functional districts (industrial and housing) of town. Water was taken from 
the same wells four times per year. At all there have been taken 114 water and 42 sediment samples from these 29 dug wells.

All soil and sediment samples were air-dried, sieved through nylon sieves taking fraction $<1 \mathrm{~mm}$. After organic matter mineralization at $450^{\circ} \mathrm{C}$ they were pulverised. Then they were analysed by DC Arc Emission Spectrometry for determination of B, Ga, $\mathrm{P}, \mathrm{Mn}, \mathrm{Ti}, \mathrm{V}, \mathrm{Cr}, \mathrm{Co}, \mathrm{Ni}, \mathrm{Cu}, \mathrm{Zn}, \mathrm{Pb}, \mathrm{Mo}, \mathrm{Ag}, \mathrm{Sn}, \mathrm{Zr}, \mathrm{Y}, \mathrm{Sc}, \mathrm{Ba},(\mathrm{Sr}$ ) content and by XRF for Sr, As, U (in soil). Reference materials OOKO 153 (SP-2) and OOKO 151 (SP-3) have been used for quality control of spectral analysis results. Acidity-alkalinity potential $(\mathrm{pH})$ was measured in all samples. Chloroform bitumoid analysis was carried out in air-dry material by luminescentic-bitominologic method.

Water samples have been analysed for trace elements by graphite furnace atomic absorption spectrometry (AAS). Migration forms of chemical elements were investigated from extremely contaminated territories ("Tikslioji mechanika", "Lietkabelis", "Aurida" and "Metalistas"). They were determined by sequential extraction method. Mobile forms (water-soluble and exchangeable) were extracted with solution of ammonium acetate $\left(1 \mathrm{~N} \mathrm{NH}_{3} \mathrm{COOH}_{3}\right)$ of $\mathrm{pH}=7$ and then - with the same solution of $\mathrm{pH}=4.8$.

\section{Methods of data treatment and interpretation}

Distinguishing of element associations was based on correlation matrix and sorted factor loading matrix obtained by principal component analysis and rotated by varimax method with the help of corresponding SPSS program. Supposing lognormal distribution of microelements, the logarithms of data recalculated to air-dry material were taken.

The local background values of elements in topsoil were estimated after consecutive elimination of anomalies described by Zinkute (1995) on the basis of 88 mainly sandy samples taken on the territory of water-intake of Panevezzs (TABLE 1). Element background values for river sediments were determined on the basis of their amounts in sediments of Nevežis and in its tributaries situated upstream from Panevèžys (TABLE 1). Concentration coefficients in soil and sediments were calculated dividing the amount determined in each sample by local background values. Total contamination index $\left(Z_{s}\right)$ was calculated by summing up concentration coefficients of main elementscontaminants according to methodical recommendations (1987).

Soil contamination level or geohygienic state was evaluated on the basis of total contamination index values using the recommended levels (1987) and in comparison with the highest allowable element concentrations in soil $\mathrm{HAC}_{\mathrm{s}}$ given in hygienic norms HN-60-1996 (1996) (TABLE 1). Control of water contamination was done according to HN-48-1994 (1994). Chemical element toxicity and danger were evaluated on the basis of reference data (1984).

Surface mapping system Surfer for Windows was used for compiling of maps. Monoelement geochemical maps of main contaminants show variability of concentration coefficients in town topsoil and Nevéžis sediments. Such maps were also compiled for territories of plants. Distribution of oil products was shown in $\mathrm{g} / \mathrm{kg}$. For evaluation of contamination danger for biota maps of total contamination index $\left(Z_{s}\right)$ were compiled where the town territory or separate objects are subdivided according to risk of pollution.

For comparison of chemical element distribution in topsoil of different parts of Panevežys, its territory was subdivided into 9 functional districts according to dominant kind of activity and therefore also contamination. 
Notes: $\mathrm{Hg}$ was not investigated at all. Be, W, Cd, Sb concentrations were usually below detection limit of DC Arc ES. $U$ and As were not investigated in river sediments. $\mathrm{Li}$ and $\mathrm{La}$ were investigated in topsoil of town and $\mathrm{Ce}$, as a rule, was below detection limit. $\mathrm{La}, \mathrm{Ce}, \mathrm{Rb}, \mathrm{Li}, \mathrm{Yb}$ and $\mathrm{Nb}$ were also determined in river sediments.

Element local background values in Panevéžys and norms in different media

\begin{tabular}{|c|c|c|c|c|c|}
\hline \multirow{2}{*}{ Elements } & \multicolumn{2}{|c|}{$\begin{array}{c}\text { Local } \\
\text { background } \\
\text { values, ppm }\end{array}$} & \multicolumn{2}{c|}{$\begin{array}{c}\text { HACs for soil } \\
\text { HN-60-1996 }\end{array}$} & \multicolumn{2}{c|}{$\begin{array}{c}\text { Water for } \\
\text { consuming }\end{array}$} \\
\cline { 3 - 6 } & \multirow{2}{*}{$\begin{array}{c}\text { In } \\
\text { topsoil }\end{array}$} & $\begin{array}{c}\text { In river } \\
\text { sediments }\end{array}$ & $\begin{array}{c}\text { Total } \\
\text { amount }\end{array}$ & $\begin{array}{c}\text { Mobile } \\
\text { form }\end{array}$ & $\begin{array}{c}\text { Water for consuming } \\
\text { (HN-48-1994) }\end{array}$ \\
\hline $\mathrm{Cd}$ & - & - & 3 & - & 0,003 \\
\hline $\mathrm{Hg}$ & - & - & 1,5 & - & 0,0005 \\
\hline $\mathrm{Pb}$ & 13 & 11,4 & 32 & 6 & 0,03 \\
\hline $\mathrm{As}$ & 4,4 & - & 2 & - & 0,05 \\
\hline $\mathrm{Zn}$ & 32 & 43,1 & - & 23 & 1 \\
\hline $\mathrm{Ba}$ & 340 & 410 & - & - & 0,1 \\
\hline $\mathrm{Cr}$ & 28 & 37 & - & 6 & 0,05 \\
\hline $\mathrm{Ni}$ & 8,8 & 13,5 & - & 4 & 0,02 \\
\hline $\mathrm{Cu}$ & 8,3 & 13,3 & - & 3 & 1 \\
\hline $\mathrm{Mo}$ & 0,6 & 1,0 & - & - & 0,25 \\
\hline $\mathrm{Sb}$ & - & - & 4,5 & - & 0,005 \\
\hline $\mathrm{Co}$ & 3,6 & 4,5 & - & 5 & 0,1 \\
\hline $\mathrm{B}$ & 25 & 30 & - & - & 0,5 \\
\hline $\mathrm{V}$ & 29 & 30 & 150 & - & 0,1 \\
\hline $\mathrm{Sr}$ & 80 & 140 & - & - & 7 \\
\hline $\mathrm{Mn}$ & 260 & 850 & 1500 & - & 0,1 \\
\hline $\mathrm{Sn}$ & 1,8 & 2,1 & - & - & - \\
\hline $\mathrm{Ag}$ & 0,07 & 0,11 & - & - & 0,01 \\
\hline $\mathrm{Be}$ & - & - & - & - & -001 \\
\hline $\mathrm{W}$ & - & - & - & - & - \\
\hline $\mathrm{U}$ & 3,2 & - & - & - & 05 \\
\hline & & & & & - \\
\hline
\end{tabular}

\section{Results}

The following main associations were distinguished in topsoil on the basis of factor analysis results: 1) $\mathrm{Cr}, \mathrm{Mo}, \mathrm{Cu}, \mathrm{Ni}, \mathrm{Sn}, \mathrm{Zn}, \mathrm{Co}, \mathrm{Mn}, \mathrm{Ag}, \mathrm{As}$, part of $\mathrm{Pb}$ and $\mathrm{V}$ (technogenous), 2) Ti, $\mathrm{Zr}, \mathrm{Y}, \mathrm{B}$ and part of $\mathrm{V}$ and $\mathrm{Sc}$ (natural clastogene), 3) $\mathrm{Sr}, \mathrm{Ba}, \mathrm{Pb}$ and part of $Y, U, Z n$ (technogenous), 4) Ga, Sc, V, part of B and Co (natural lithogenic).

According to this it was concluded that there are 14 main elements-contaminants of the town: $\mathrm{Pb}, \mathrm{Zn}, \mathrm{Cu}, \mathrm{Ni}, \mathrm{Ba}, \mathrm{Sn}, \mathrm{Mn}, \mathrm{Mo}, \mathrm{Sr}, \mathrm{Ag}, \mathrm{Cr}, \mathrm{Co}, \mathrm{V}$, and As. All of them were included to total contamination index and monoelement maps were compiled for all except As. The median values of these elements content in different functional 
districts of town indicate that the most heavily contaminated are Pušalotas $(\mathrm{Cu}, \mathrm{Sn}, \mathrm{Mo}$, $\mathrm{Ni}, \mathrm{Cr}, \mathrm{Mn}$ ), the Old town $(\mathrm{Pb}, \mathrm{Sr}, \mathrm{Ba}, \mathrm{Zn})$, and Tinklai $(\mathrm{V}, \mathrm{Co})$ industrial districts (TABLE 2). Besides, the greatest amount of $\mathrm{Ag}$ is observed in the Centre of the town and maximum median value of $\mathrm{V}$ - on the territory of gleyic water-intake territory. Therefore median values of $V$ on the town territory are more suitable as background in calculation of concentration coefficients.

Table 2

\section{Chemical elements-contaminants median values in topsoil of various functional districts of Panevèžys, ppm}

\begin{tabular}{|c|c|c|c|c|c|c|c|c|c|c|c|c|c|c|}
\hline \multirow{2}{*}{$\begin{array}{l}\text { No of } \\
\text { district }\end{array}$} & istrict 1 & $\mathrm{~Pb}$ & $\mathrm{Cu}$ & $\mathrm{Zn}$ & $\mathrm{Sn}$ & $\mathrm{Ag}$ & Mo & $\mathrm{Ni}$ & $\mathrm{Cr}$ & $\mathrm{Mn}$ & $\mathrm{V}$ & $\mathrm{Co}$ & $\mathrm{Sr}$ & $\mathrm{Ba}$ \\
\hline & \multicolumn{14}{|c|}{ Housing } \\
\hline$I$ & & 15,1 & 10,8 & 9,1 & 1,9 & 0,074 & 0,65 & 11,0 & 29,6 & 314 & 3,4 & 17 & 92 & 59 \\
\hline \multirow[t]{2}{*}{$\overline{I V}$} & & 19,7 & 10,5 & 24,6 & 2,0 & 0,075 & 0,58 & 11,4 & 32,0 & 314 & 23,5 & 37 & 94 & 475 \\
\hline & \multicolumn{14}{|c|}{ Industrial } \\
\hline II & & 39,6 & 26,8 & 72,0 & 3,6 & 0,089 & 0,98 & 16,3 & 40,9 & 376 & 26,8 & 4,62 & 107 & 507 \\
\hline III & & 16,7 & 12,2 & 28,1 & 2,0 & 0,061 & 0,75 & 13,5 & 32,0 & 311 & 23,7 & 4,36 & 111 & 467 \\
\hline $\mathrm{V}$ & he & 50,8 & 14,9 & 91,0 & 2,6 & 0,092 & 0,85 & 15,7 & 36,9 & 371 & 27,9 & 4,12 & 116 & 566 \\
\hline $\mathrm{VI}$ & & 28,8 & 12,1 & 32,7 & 2,3 & 0,077 & 0,67 & 14,4 & 35,3 & 362 & 28,2 & 4,85 & 99 & 513 \\
\hline \multirow[t]{2}{*}{ VII } & & 27,0 & 13,9 & 56,5 & 2,4 & 0,084 & 0,82 & 13,2 & 32,7 & 340 & 25 & 4,13 & 95 & 424 \\
\hline & \multicolumn{14}{|c|}{ Other } \\
\hline VIII & & 24,9 & 13,2 & 74,5 & 2,6 & 0,119 & 0,72 & 13,0 & 33,5 & 350 & 27,4 & 4,30 & 95 & 469 \\
\hline IX & Water-intake & 12,3 & 7,7 & 14,0 & 1,9 & 0,068 & 0,56 & 8,6 & 28,6 & 254 & 28,7 & 3,43 & 80 & 315 \\
\hline
\end{tabular}

According to Kadūnas et al. (1995) the main pollution sources in the town are metal processing enterprises. Zones with dangerously and extremely dangerously contaminated topsoil including the territory of the plant and part of its sanitary zone had formed around some isolated plants. In industrial districts metal processing enterprises form large zones with different topsoil contamination level (from medium to extremely dangerous) while they are functioning in close proximity. Certain contaminating elements can reflect the type of main technologic processes used in the enterprise. For example, a distinct lead anomaly including part of the Old town industrial district with huge influence on total geohygienic status of soil had formed from aerosols emitted in "Ekranas" plant (FIG. 1, A). In the centre of aureole on the plant territory the concentration of lead exceeds the local natural background several hundred times and also exceeds its highest allowable concentration. In topsoil of the Pušalotas industrial district the most distinct is copper anomaly which was formed by aerosols emitted from "Lietkabelis" (cable plant) and "Tikslioji mechanika" (plant of precise mechanics) (FIG. $1, \mathrm{~B})$. One more important contaminant of town is "Metalistas" with metal casting and galvanic processes used in its activity (FIG. 2).

According to Baltakis and Radzevičius (1995) transport enterprises can also be important source of town pollution. However, in Panevėžys transport, food, light industry and other types of industrial enterprises as well as thermal electric power stations are not so heavily contaminated (FIG.3).

The elements-contaminants in heavily polluted areas accumulate in different migration forms. According to the content of mobile forms in soil the elements can be arranged in the following way: $\mathrm{Pb}>\mathrm{Cd}>\mathrm{Zn}>\mathrm{Mn}>\mathrm{Ni}>\mathrm{Cu}>\mathrm{Co}>\mathrm{Cr}$. Extremely dangerous to biota is $\mathrm{Pb}$ contamination in "Ekranas" because its mobile forms can be found even at $0,6 \mathrm{~m}$ depth. 


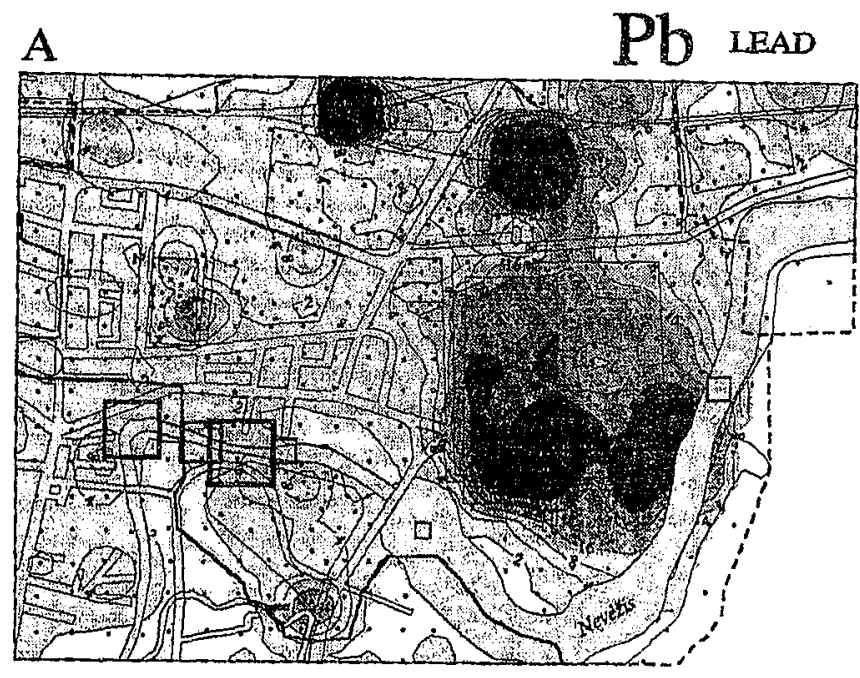

\section{COEFFICIENTS OF CONCENTRATION}

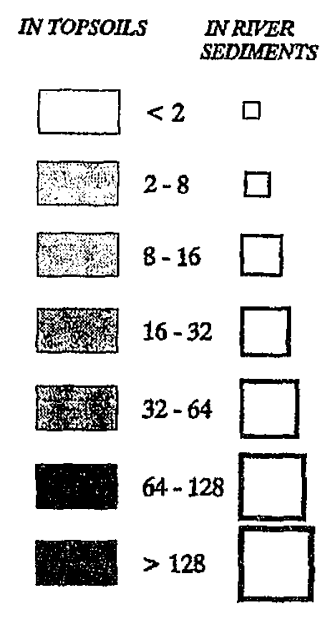

- Sampling points

B

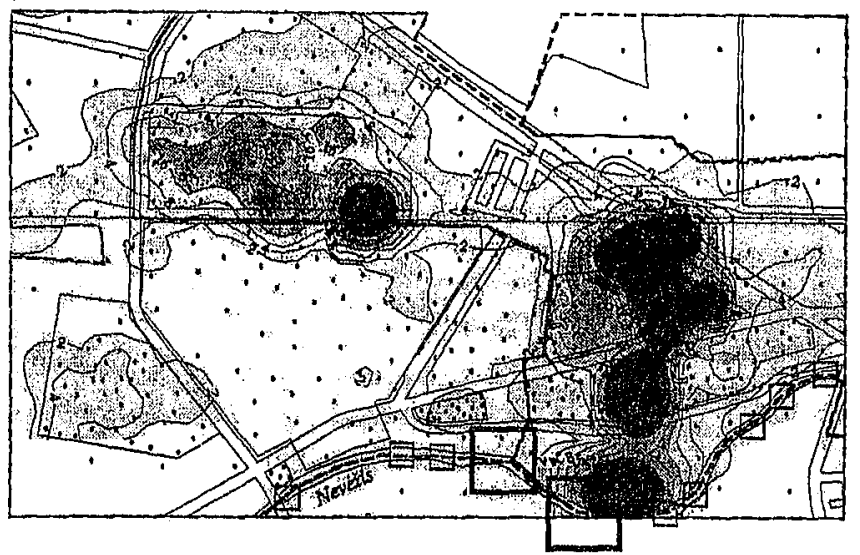

$\mathrm{Cu}$ copper

FIG. 1. Distribution of elements in topsoil and river sediments in different districts of Panevežys (A - the Old town district with "Ekranas" TV-tubes plant, metal processing plants "Metalistas" and "Panevéžio ketus"; B - Pušalotas district with plant of precise mechanics, plant of cables and plant of autocompressors)

Due to change of physical-chemical parameters of environment part of elementscontaminants accumulated in topsoil can migrate to deeper soil horizons, reach the groundwater and accumulate in dug wells. The other part of them together with surface runoff can find themselves either in untidy dug wells or in Nevezis. According to Radzevičius et al. (1995) Nevéžis sediments are affected by technogenous pollution. Toxic elements accumulate in water sediments reaching dangerous to biota concentration level.

In Nevéžis sediments 3 main associations have been distinguished: 1)Zn, Ce, La, $\mathrm{Sr}, \mathrm{Ba}, \mathrm{Pb}, \mathrm{Y}$ (the main source - TV-tubes plant "Ekranas"), 2) $\mathrm{Mo}, \mathrm{Cu}, \mathrm{Sn}, \mathrm{Ag}$ and $\mathrm{P}$ (related with organic matter content, main sources of $\mathrm{Cu}$ and $\mathrm{Sn}$ are electrical engineering plants), 3) $\mathrm{Cr}, \mathrm{Ni}$ and $\mathrm{Nb}$ ( $\mathrm{Cr}$ and $\mathrm{Ni}$ are typical contaminants emitted in galvanic shops of metal processing plants, especially downstream from "Metalistas". 

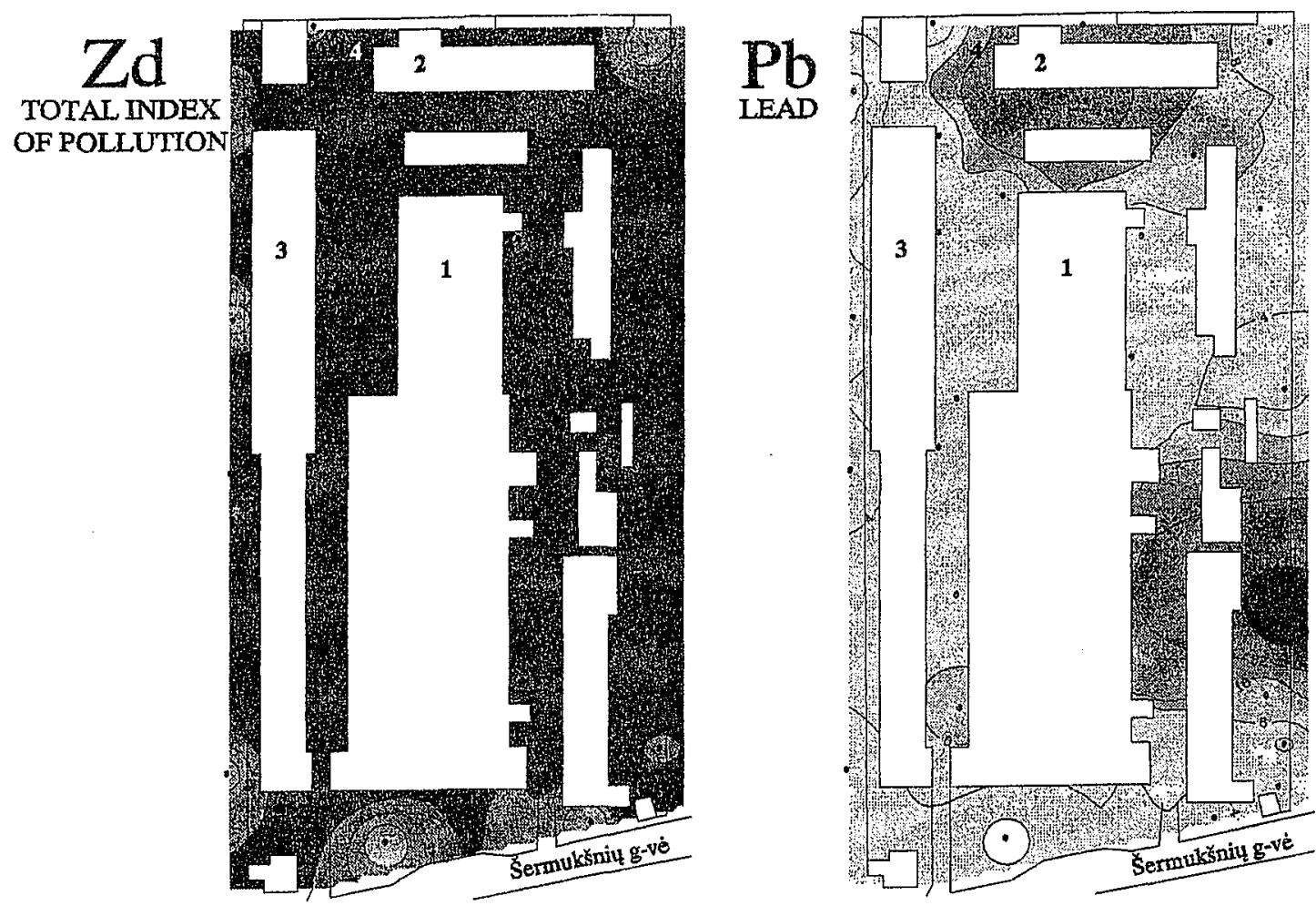
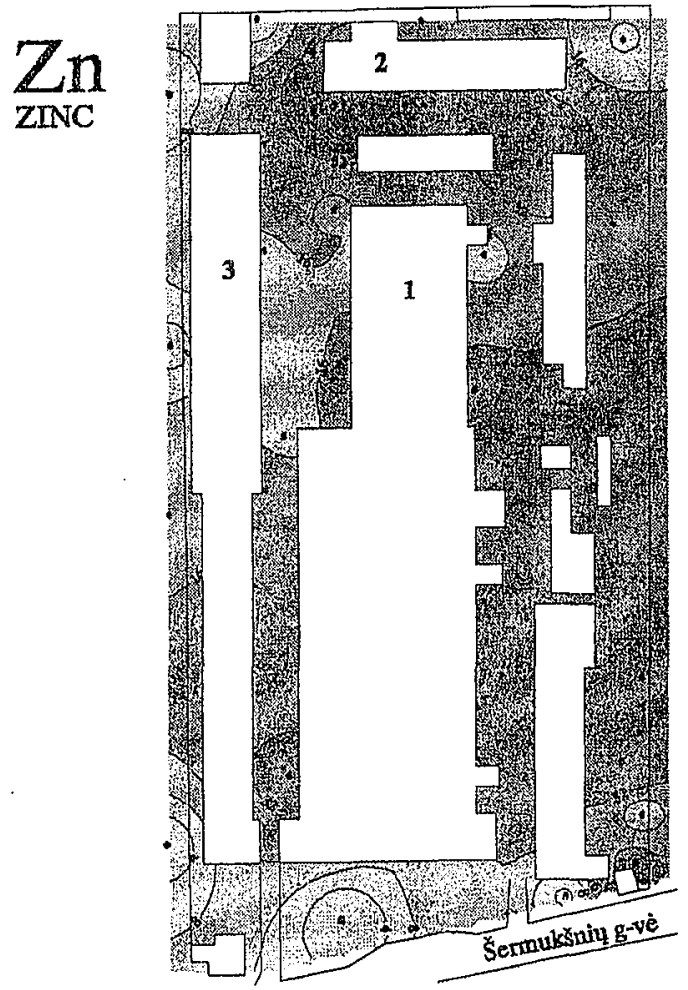
$\begin{array}{cc}\text { COEFEICIENTS OF } & \text { POLLUTION } \\ \text { CONCENTRATION } & \text { LEVEL ACCORDING } \\ \text { IN TOPSOILS } & \text { TO INDEXZS }\end{array}$ IN TOPSOILS TO INDEX ZS

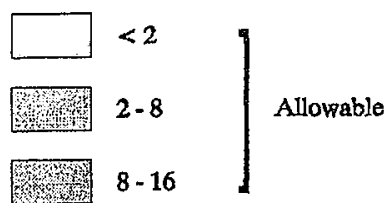

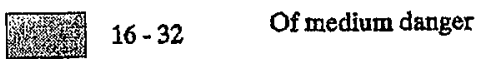

$\left.\begin{array}{l}32-64 \\ 64-128\end{array}\right]$ Dangerous

$>128 \quad$ Extremely dangerous

- Sampling points

FIG. 2. Distribution of elements and total contamination index in topsoil of metal processing plant "Metalistas" (1 - galvanic shop, 2 - ventilator site, 3 - casting shop) 


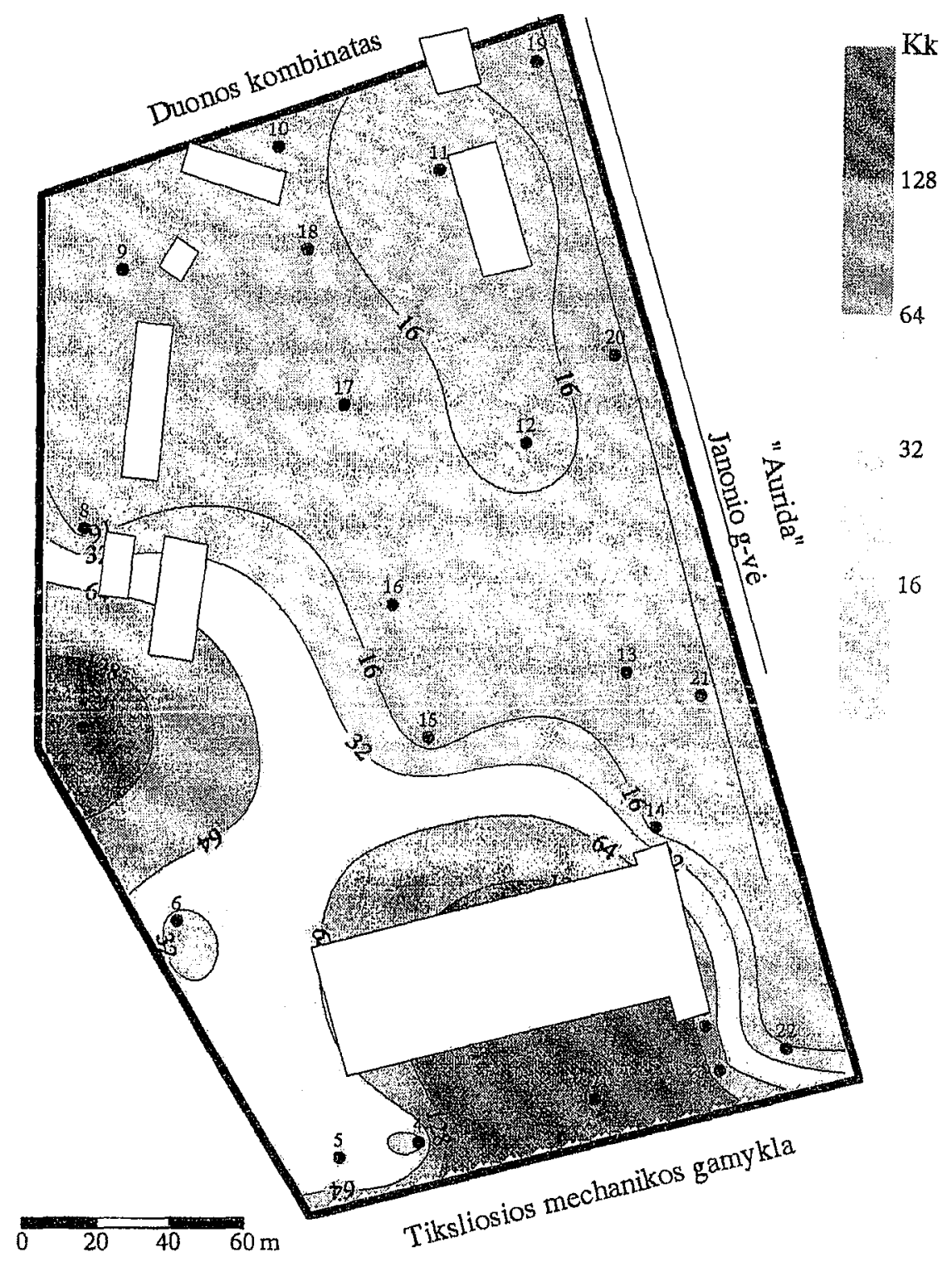

FIG. 3. Distribution of total contamination index in topsoil of motor transport enterprise "Atra"

The accumulating associations in different media of Panevėžys are rather similar and indicate that $\mathrm{Pb}$ and $\mathrm{Zn}$ are the main pollutants of the town (TABLE 3). For main contaminants the accumulation level both in Nevéžis and in dug wells sediments is greater than in topsoil. The greatest accumulation of $\mathrm{Pb}, \mathrm{Sr}, \mathrm{Ba}, \mathrm{Ag}$ and $\mathrm{V}$ is observed in river sediments while the greatest content of other elements is in dug wells sediments. This must be due to great sorption capacity of fine mud in wells and alkaline barrier forming there. The infiltration of pollutants to dug wells is small as they are well protected by the thick aeration zone. They get to the wells mainly with surface runoff, therefore good care should be taken of them. Though heavy metal concentration in water of dug wells usually does not exceed the standard norms for water consuming HN-48-1994 (1994) but the increase of acidity can cause water pollution problems. 
Table 3

Accumulating associations and comparison of element accumulation level in different media Panevežys

\begin{tabular}{|c|c|c|c|c|c|c|c|c|c|}
\hline \multicolumn{2}{|c|}{ In topsoil } & \multicolumn{2}{|c|}{$\begin{array}{l}\text { In Nevežzis } \\
\text { sediments }\end{array}$} & \multicolumn{2}{|c|}{$\begin{array}{l}\text { In dug wells } \\
\text { sediments }\end{array}$} & \multirow[t]{2}{*}{$\begin{array}{l}\text { Ele- } \\
\text { ments }\end{array}$} & \multicolumn{3}{|c|}{ Accumulation level } \\
\hline $\begin{array}{c}\text { Ele- } \\
\text { ments }\end{array}$ & $\mathrm{CC}$ & $\begin{array}{c}\text { Ele- } \\
\text { ments }\end{array}$ & $\mathrm{CC}$ & $\begin{array}{c}\text { Ele- } \\
\text { ments }\end{array}$ & $\mathrm{CC}$ & & In topsoil & $\begin{array}{l}\text { In Nevéžis } \\
\text { sediments }\end{array}$ & $\begin{array}{c}\text { In dug wells } \\
\text { sediments }\end{array}$ \\
\hline $\mathrm{Pb}$ & 2,09 & $\mathrm{~Pb}$ & 19,08 & $\mathrm{Zn}$ & 10,14 & $\mathrm{Zn}$ & 1,69 & 4,61 & 10,14 \\
\hline $\mathrm{Zn}$ & 1,69 & $\mathrm{Zn}$ & 4,61 & $\mathrm{~Pb}$ & 6,99 & $\mathrm{Cu}$ & 1,63 & 2,89 & 4,64 \\
\hline $\mathrm{Cu}$ & 1,63 & $\mathrm{Sr}$ & 3,85 & $\mathrm{Cu}$ & 4,64 & $\mathrm{~Pb}$ & 2,09 & 19,08 & 6,99 \\
\hline $\mathrm{Ni}$ & 1,55 & $\mathrm{Cu}$ & 2,89 & $\mathrm{Ni}$ & 2,12 & $\mathrm{Cr}$ & 1,22 & 1,42 & 2,08 \\
\hline $\mathrm{Ba}$ & 1,40 & $\mathrm{Ag}$ & 2,18 & $\mathrm{Cr}$ & 2,08 & $\mathrm{Ni}$ & 1,55 & 1,93 & 2,12 \\
\hline $\mathrm{Sn}$ & 1,36 & $\mathrm{Ni}$ & 1,93 & Mo & 1,94 & Co & 1,19 & 1,43 & 1,65 \\
\hline $\mathrm{Mn}$ & 1,34 & $\mathrm{Ba}$ & 1,88 & $\mathrm{Sn}$ & 1,78 & Mo & 1,25 & 1,13 & 1,94 \\
\hline Mo & 1,25 & V & 1,43 & $\mathrm{Mn}$ & 1,67 & $\mathrm{Sn}$ & 1,36 & 1,37 & 1,78 \\
\hline $\mathrm{Sr}$ & 1,25 & Co & 1,43 & Co & 1,65 & $\mathrm{Ag}$ & 1,23 & 2,18 & 1,43 \\
\hline $\mathrm{Ag}$ & 1,23 & $\mathrm{Cr}$ & 1,42 & $\mathrm{Ba}$ & 1,54 & $\mathrm{Mn}$ & 1,34 & 0,80 & 1,67 \\
\hline $\mathrm{Cr}$ & 1,22 & Sn & 1,37 & $\mathrm{Ag}$ & 1,43 & $\mathrm{Ba}$ & 1,40 & 1,88 & 1,54 \\
\hline Co & 1,19 & Mo & 1,13 & $\mathrm{Sr}$ & 1,39 & $\mathrm{Sr}$ & 1,25 & 3,85 & 1,39 \\
\hline U & 1,13 & B & 1,08 & $B$ & 1,30 & $\mathrm{~V}$ & 0,91 & 1,43 & 0,70 \\
\hline$B$ & 1,07 & $\mathrm{Mn}$ & 0,80 & $\mathrm{U}$ & 0,96 & $B$ & 1,07 & 1,08 & 1,30 \\
\hline V & 0,91 & & & As & 0,79 & As & 0,85 & & 0,79 \\
\hline As & 0,85 & & & V & 0,70 & $\mathrm{U}$ & 1,13 & & 0,96 \\
\hline
\end{tabular}

Notes: CC - median values of concentration coefficients. For calculation of concentration coefficients in topsoil and in dug wells' sediments the background values in topsoil were used, while in Nevežis sediments - the local background values in river sediments.

\section{Conclusions}

1.Topsoil geochemical mapping enables to find out the main sources of pollution in the urbanised territories. Investigation of additional sampling media (river sediments, dug wells water and sediments) helps to find out the ways of further migration of the elements and their danger to biota.

2.Geochemical investigations of Panevèžys have shown that the greatest contamination is in industrial districts of the town while housing districts are not dangerously polluted. The main contamination sources in urbanised territories are metal processing enterprises with metal casting and other high temperature processes, electrochemical technologies. They form multielement anomalies of ferrous and nonferrous metals with heavy contamination in topsoil. Transport enterprises are also important but not such intensive pollution sources. They are usually heavily contaminated by oil products. Other kind of activity (food industry, energetics) causes less dangerous contamination.

3. Geochemical investigations in Panevèžys have shown that there is intensive migration of pollutants with surface runoff and sewers to Nevežzis river and accumulation in its sediments. Accumulation of pollutants in well sediments is also observed, though in water the allowable limits are not exceeded. Similarity between 
paragenetic and accumulating associations in topsoil and river sediments indicates that the main pollution sources can be traced even in river sediments ( $\mathrm{Pb}-\mathrm{Sr}-\mathrm{Ba}$ association formed by "Ekranas" plant).

4.According to geochemical investigations in Panevéžys the pollutants get into water and sediments of dug wells mainly through surface runoff and are sorbed by the sediments. Though their concentration in water usually does not exceed the standard norms good care should be taken of them.

\title{
References
}

GeOCHEMICAL Atlas of PANEvėŽYs, 1997, M 1:25000, Tverkutè, Z. (Panevéžys Municipality), Radzevičius, A., Budavičius, R., Kadūnas, V., Katinas, V., Zinkutè, R. (Institute of Geology), (Vilnius-Panevezžys, in English and Lithuanian), p. 18, 25 maps. HN-60-1996, 1996, 'Kenksmingos medžiagos. Didžiausia leidžiama ir laikinai leidžiama koncentracija dirvožemyje', (Vilnius), p. 16.

HN-48-1994, 1994, 'Kenksmingos medžiagos. Didžiausia leidžiama koncentracija ir laikinai leidžiamas lygis žmogaus vartojamame vandenyje', (Vilnius), p. 42.

BALTAKIS, V., RADZEVIČIUS, A., 1995, 'Transporto imonių teritorijų užterštumas sunkiaisiais metalais ir naftos produktais', Geologijos mokslo pasiekimai-gamtosaugai, (Vilnius), pp. 16-19.

KADŪNAS, V., KATINAS, V., RADZEVIČIUS, A., TARAŠKEVIČIUS, R., ZINKUTÉ, R., 1995, 'Metalo apdirbimo imonių teritorijų grunto užterštumo ekologinis-geocheminis ivertinimas', Geologijos mokslo pasiekimai - gamtosaugai, (Vilnius), pp. 13-15.

RADZEVIČIUS, A., ZnNKUTĖ, R., 1995, 'Nevèžio upès dugno nuosèdų užterštumas pavojingais cheminiais elementais Panevezzio mieste', Molsslas. Technologija. Verslas, (Pranešimų medžiaga (III), Panevéžys), pp. 52-53.

ZINKUTE, R., 1995, 'Panevéžio miesto dirvožemio geocheminis fonas', Mokslas, technologija, verslas, (Panevéžys) pp.50-51.

ВРЕДНЫЕ ХИМИЧЕСКИЕ ВЕЩЕСТВА, 1988-1989, (Справочник, Т.1-2, Ленинград: Химия), p. 512.

МЕТОДИЧЕСКИЕ УКАЗАНИЯ ПГО ОІЕНКЕ СТЕПЕНИ ОПАСНОСТИ ЗАГРЯЗНЕНИЯ ПОЧВЫ ХИМИЧЕСКИМИ ВЕЩЕСТВАМИ, 1987, (МосКва), р. 27.

\section{SAPROPELA PLŨSMAS MODELẼ ŠANA MODELLING OF SAPROPEL FLOW}

\author{
AIVARS KAK İTIS, $\mathrm{Mg}$. ing. \\ Mehānikas institūts, Latvijas Lauksaimniecỉbas universitāte \\ J.Čakstes bulv. 5, Jelgava, Latvija, LV - 3001
}

\begin{abstract}
The most important problem for sapropel extraction by means of pumping systems is the reduction of energy costs for the transportation of pure humidity sapropel in pipelines. The main parameters, which create energy losses in the flow, are: plastic viscosity $\mu_{p}$ and boundary shearing stress $\tau_{0}$. The article presents results of mathematical modelling of pure sapropel flow. An equation is worked out which describes changes of shear stress in dependence of shear rate in the pure sapropel flow. The equation can be used for modelling different non-Newtonian plastic fluids with nonlinear flow curves. The equation gives good accordance between theory and results of the experiment. Coefficient of determination reaches value $R^{2}=0.92-0.98$
\end{abstract}

